\title{
Comprehensive Investigation into the Exergy Values of Six Rice Husks
}

\author{
${ }^{1,2}$ Yaning Zhang, ${ }^{1}$ A.E. Ghaly and ${ }^{2}$ Bingxi Li \\ ${ }^{1}$ Department of Process Engineering and Applied Science, Dalhousie University, Halifax, Canada \\ ${ }^{2}$ School of Energy Science and Engineering, Harbin Institute of Technology, Harbin, China
}

Received 2013-06-09, Revised 2013-06-10; Accepted 2013-06-10

\begin{abstract}
Exergy is a measurement of how far a certain system or material deviates from a state of equilibrium with the environment and it is a useful tool for improving the efficiency of energy-resource use. Based on the previous work, the exergy values of six rice husks were investigated in this study. The effects of physical and chemical properties were also detailed. These included moisture content, ash content, $\mathrm{S}, \mathrm{C}, \mathrm{O}, \mathrm{H}$ and $\mathrm{N}$ contents. The moisture related exergy of the six rice husks ranged in 241.432-290.304 kJ per kg rice husk, accounting for $1.563-1.758 \%$ of the exergy of rice husks. An exponential relationship between exergy value and moisture content was observed. The exergy of ash varied between $37.419 \mathrm{~kJ}$ per $\mathrm{kg}$ rice husk and $61.217 \mathrm{~kJ}$ per $\mathrm{kg}$ rice husk, making up $0.233-0.401 \%$ of the exergy of rice husks. An exponential linear relationship between exergy value and ash content was observed. The $\mathrm{S}$ related exergy ranged from 1.217 $\mathrm{kJ}$ per $\mathrm{kg}$ rice husk to $2.993 \mathrm{~kJ}$ per $\mathrm{kg}$ rice husk, accounting for $0.007-0.018 \%$ of the exergy of rice husks. The $\mathrm{O} / \mathrm{C}, \mathrm{H} / \mathrm{C}$ and $\mathrm{N} / \mathrm{C}$ atomic ratios varied in ranges of $0.592-0.662,1.404-1.730$ and $0.008-0.011$, respectively, whereas the correlation factors varied slightly in the range of 1.118-1.127. The exergy values of the six rice husks ranged in $15.053-18.407 \mathrm{MJ} / \mathrm{kg}$. They were mainly determined by the correlation factors and the LHVs. A positive linear relationship between exergy value and LHV was observed.
\end{abstract}

Keywords: Exergy, Rice Husk, Moisture, Ash, S, C, O, H, N, Correlation Factor

\section{INTRODUCTION}

Rice is a staple food for over half of the world's population and about one-fifth of the world's population is engaged in rice cultivation (Reidy, 2011). The global paddy rice production continued to increase at an average rate of 16.48 million tonnes per year during the last ten years (Zhang et al., 2012), reaching about 718.3 million tonnes in 2011 (FAO, 2011). This paddy rice produces the largest amount of crop residues in the forms of rice straw and rice husk (Soest, 2006).

Rice husk is one of the main residues from rice cultivation and processing. It is abundantly available and renewable and has been used as fertilizer and animal feed (Vadiveloo et al., 2009). It can also be used as an energy source in thermochemical conversion processes such as gasification and combustion (Zhao et al., 2012; Martínez et al., 2011) or in bioconversion processes for production of bio-oil ( $\mathrm{Lu}$ et al., 2012) and biogas (Kuo et al., 2011). The ash produced from gasification and combustion processes can be used as a supplementary material in cement and ceramic manufacturing (Zain et al., 2011).

The physical and chemical properties of rice husk are wildly studied. These include moisture content, bulk density, particle size, porosity, heating values, proximate analysis, ultimate analysis, ash composition and ash characteristics (Mansaray and Ghaly, 1997; Zhang et al., 2012; Shen et al., 2012; Kaewkhao and Limsuwan, 2012). However, the exergy of rice husk has not been reported. The main objectives of this study were: (a) to investigate the exergy values of rice husks from six varieties of rice and (b) to determine the effects of physical and chemical properties (moisture content, ash content, S, C, O, H and N contents) on the

exergy values of rice husks.

Nova Scotia; Canada Tel: (902)494-6014; E-mail:abdel.ghaly@dal.ca. 


\section{EXERGY ANALYSIS OF BIOMASS FUELS}

Exergy is the amount of work obtainable when a matter is brought to a state of thermodynamic equilibrium with the common components of the natural surroundings such as environmental condition by means of reversible processes, involving interaction only with the above mentioned components of nature (Szargut, 1980). Wall (1986) stated that exergy is a measurement of how far a certain system deviates from a state of equilibrium with its environment. Unlike energy, exergy is not subject to conservation law (except for ideal or reversible processes). It is consumed or destroyed due to unavoidable irreversibilities in any real process. The exergy consumption during a process is proportional to the entropy created due to irreversibilities associated with the process (Rosen and Bulucea, 2009).

Exergy analysis is a methodology that uses the conservation of energy principle (embodied in the first law of thermodynamics) together with non-conservation of entropy principle (embodied in the second law) for the analysis, design and improvement of energy and systems (Rosen and Bulucea, 2009; Dincer, 2002). The exergy method is useful for improving the efficiency of energy-resource use, for it quantifies the locations, types and magnitudes of wastes and losses. In general, more meaningful efficiencies can be evaluated with exergy analysis rather than energy analysis, since exergy efficiencies are always a measure of the approach to the ideal condition (Rosen and Bulucea, 2009).

The exergy of a material can be calculated from its chemical potential and concentrations in its actual state and reference state (Wall, 1986). For irregular materials such as compounds with unknown chemical potential, the exergy values can not be obtained. Szargut et al. (1988) proposed a statistical method for representing the exergy of biomass fuels:

$$
\text { ex }=\beta\left(L H V+\eta_{w} h_{w}+9683 \eta_{s}+e x_{\text {ash }} \eta_{a s h}+e x_{w} \eta_{w}\right.
$$

\section{where:}

ex is the exergy of the fuels $(\mathrm{kJ} / \mathrm{kg})$

$\beta \quad$ is the correlation factor

$h_{\mathrm{w}} \quad$ is the evaporation enthalpy of moisture (2442kJ/kg (Szargut et al., 1988))

$\eta_{\mathrm{w}} \quad$ is the moisture content (\%)

$\eta_{\mathrm{s}} \quad$ is the weight percentage of sulfur (\%)

$\eta_{\text {ash }} \quad$ is the weight percentage of ash (\%) $e x_{\text {ash }} \quad$ is the exergy of ash $(\mathrm{kJ} / \mathrm{kg})$

$e x_{\mathrm{w}} \quad$ is the exergy of water $(900 \mathrm{~kJ} / \mathrm{kmol})$

$L H V$ is the lower heating value of biomass fuels $(\mathrm{kJ} / \mathrm{kg})$

Moran et al. (2011) reported the exergy of water was $900 \mathrm{~kJ} / \mathrm{kmol}$. Szargut et al. (1988) gave the following equations for the correlation factor:

(a) For solid hydrocarbons Equation 2:

$\beta=1.0435+0.0159 \frac{\mathrm{H}}{\mathrm{C}}$

(b) For solid fuels containing C, $\mathrm{H}$ and $\mathrm{O}$ (Equations 3 and 4):

$$
\beta=1.0438+0.0158 \frac{\mathrm{H}}{-}+0.0813 \frac{\mathrm{O}}{\mathrm{O}}(\mathrm{O} / \mathrm{C} \leq 0.5)
$$

$$
\beta=\frac{1.0414+0.0177 \frac{\mathrm{H}}{\mathrm{C}}-0.3328 \frac{\mathrm{O}}{\mathrm{C}}\left(1+0.0537 \frac{\mathrm{H}}{\mathrm{C}}\right)}{1-04021 \frac{\mathrm{O}}{\mathrm{C}}}
$$

$(\mathrm{O} / \mathrm{C} \leq 2)$

(c) For solid fuels containing $\mathrm{C}, \mathrm{H}, \mathrm{O}$ and $\mathrm{N}$ (Equations 5 and 6):

$$
\begin{aligned}
& \beta=1.0437+0.0140 \frac{\mathrm{H}}{\mathrm{C}}+0.0968 \frac{\mathrm{O}}{\mathrm{C}} 0.0467 \frac{\mathrm{N}}{\mathrm{C}} \\
& (\mathrm{O} / \mathrm{C} \leq 0.5) \\
& \beta=\frac{1.044+0.0160 \frac{\mathrm{H}}{\mathrm{C}}-0.3493 \frac{\mathrm{O}}{\mathrm{C}}\left(1+0.05631 \frac{\mathrm{H}}{\mathrm{C}}\right)+000493 \frac{\mathrm{N}}{\mathrm{C}}}{1-0.4124 \frac{\mathrm{O}}{\mathrm{C}}}
\end{aligned}
$$

$(\mathrm{O} / \mathrm{C} \leq 2)$

(c) For wood (Equation 7):

$$
\beta=\frac{-0.2499 \frac{\eta_{\mathrm{O}}}{\eta_{\mathrm{C}}}\left(1+0.7884 \frac{\eta_{\mathrm{H}}}{\eta_{\mathrm{C}}}\right)+0.0450 \frac{\eta_{\mathrm{N}}}{\eta_{\mathrm{C}}}}{1-0.3035}
$$

Where:

$C$ is the number of carbon in the molecular formula of fuel

$H \quad$ is the number of hydrogen in the molecular formula of fuel 
$O \quad$ is the number of oxygen in the molecular formula of fuel

$N \quad$ is the number of nitrogen in the molecular formula of fuel

$\eta_{\mathrm{C}} \quad$ weight percentage of carbon (\%)

$\eta_{\mathrm{H}} \quad$ weight percentage of hydrogen (\%)

$\eta_{\mathrm{O}} \quad$ weight percentage of oxygen (\%)

$\eta_{\mathrm{N}} \quad$ weight percentage of nitrogen (\%)

\section{MATERIALS}

The six rice husks reported by Mansaray and Ghaly (1997) were used in this study. They were Lemont, ROK 14, ROK 16, ROK 32, CP 4 and Pa Potho. Lemont rice husk was obtained from Broussard Rice Mills in Louisiana and the other five rice husks were obtained from the West African Rice Research Station, Rokupr, Sierra Leone. The collection and processing procedures were described in the previous study (Mansaray and Ghaly, 1997).

\section{CHARACTERISTICS OF RICE HUSKS}

\subsection{Moisture Content}

The moisture contents of the six rice husks are shown in Table 1. The moisture contents of the six rice husks varied from $8.68 \%$ to $10.44 \%$. The ROK 14 rice husk had the lowest moisture content $(8.68 \%)$ whereas the ROK 16 rice husk had the highest moisture content $(10.44 \%)$. These differences may be due to variations in climatic conditions, soil type, methods of cultivation and type of used fertilizer as well as different collection and storage (Zhang et al., 2012).

\subsection{Lower Heating Value}

The LHVs of the six rice husks are presented in Table 1. The average LHV for the rice husk varieties ranged from $13.24 \mathrm{MJ} / \mathrm{kg}$ (ROK 14) to $16.20 \mathrm{MJ} / \mathrm{kg}$ (ROK 16). The reasonably good energy content of ROK 16 rice husk could be attributed to its lower ash content (Table 1) compared to the other rice husks. The LHV is also affected (significantly) by the S, C, $\mathrm{O}, \mathrm{H}$ and $\mathrm{N}$ contents.

\subsection{Ash Content and Compositions}

Ash content is an important thermochemical property of an energy resource. The ash contents of the six rice husks are shown in Table 1. The CP 4 rice husk had the highest ash content $(22.386 \%)$ whereas the ROK 16 rice husk had the lowest ash content $(13.703 \%)$.
Table 1. Moisture contents, LHVs and ash contents of rice husks (Mansaray and Ghaly, 1997).

\begin{tabular}{cccc}
\hline $\begin{array}{c}\text { Rice } \\
\text { husk }\end{array}$ & $\begin{array}{c}\text { Moisture content } \\
(\%)\end{array}$ & $\begin{array}{c}\text { LHV } \\
(\mathrm{MJ} / \mathrm{kg})\end{array}$ & $\begin{array}{c}\text { Ash content } \\
(\%)^{\mathrm{a}}\end{array}$ \\
\hline Lemont & 9.08 & 14.22 & 21.275 \\
ROK 14 & 8.68 & 13.24 & 17.168 \\
ROK 16 & 10.44 & 16.20 & 13.703 \\
ROK 32 & 10.20 & 14.60 & 16.793 \\
CP 4 & 9.00 & 13.40 & 22.386 \\
Pa Potho & 10.16 & 14.12 & 16.351 \\
\hline
\end{tabular}

${ }^{\mathrm{a}}$ On as received basis.

However, these values (13.703-22.386\%) are much higher than the $9.40 \%$ for rice straw reported by Singha and Das (2011), the 3-5\% for wheat straw reported by Ghaly and Al-taweel (1990) and the 6.57\% for coal reported by Yuan et al. (2012).

The ash content affects the property of a fuel as an energy resource. It indicates the potential for the formation of undesirable bonded deposits on combustor surfaces (Ghaly and Al-taweel, 1990).

The rice husk ashes are mainly composed of mineral oxides. The measured mineral oxides are usually $\mathrm{SiO}_{2}$, $\mathrm{K} 2 \mathrm{O}, \mathrm{CaO}, \mathrm{P}_{2} \mathrm{O}_{5}, \mathrm{MgO}, \mathrm{Al}_{2} \mathrm{O}_{3}, \mathrm{Fe}_{2} \mathrm{O}_{3}, \mathrm{Na}_{2} \mathrm{O}, \mathrm{SO}_{3}, \mathrm{TiO}_{2}$ and $\mathrm{ZnO}$. The detailed ash compositions of the six rice husks were transferred and shown in Table 2. All the rice husk varieties have high content of $\mathrm{SiO}_{2}$ $(2.0982-3.3992 \mathrm{~mol} / \mathrm{kg}$ fuel) and low content of $\mathrm{ZnO}$ $(0.0002-0.0003 \mathrm{~mol} / \mathrm{kg}$ fuel). The differences in mineral oxide concentrations could be the result of the variations in climatic conditions, soil type, methods of cultivation and type of used fertilizer (Zhang et al., 2012).

\subsection{S, C, O, $\mathrm{H}$ and $\mathrm{N}$ Contents}

Table 3 shows the $\mathrm{S}, \mathrm{C}, \mathrm{O}, \mathrm{H}$ and $\mathrm{N}$ contents of the six rice husks. Although different rice husk varieties had different $\mathrm{S}, \mathrm{C}, \mathrm{O}, \mathrm{H}$ and $\mathrm{N}$ contents, all the rice husk varieties had high content of $\mathrm{C}$ (34.186-39.854 wt.\%) followed by $\mathrm{O}$ (28.665-31.525 wt.\%), H (4.277-4.935 wt.\%), N (0.345-0.458 wt.\%) and S (0.013-0.031 wt.\%). Wen et al. (2012) reported that the S, C, O, H and N contents for coal were $0.6-1.4 \%, 53.6-73.7 \%, 3.2-16.7 \%$, $3.2-5.4 \%$ and $0.8-1.0 \%$, respectively. These S, C, O, H and $\mathrm{N}$ contents make the rice husks have much lower LHVs than coals. Shirai et al. (2012) reported a LHV range of $26.3-27.3 \mathrm{MJ} / \mathrm{kg}$ for coals.

\section{RESULTS AND DISCUSSION}

\subsection{Exergy Values of Rice Husks}

Fig. 1 shows the exergy values of the six rice husks. The exergy value was $16.290 \mathrm{MJ} / \mathrm{kg}$ for the Lemont rice husk, $15.053 \mathrm{MJ} / \mathrm{kg}$ for the ROK 14 rice husk, 18.407 $\mathrm{MJ} / \mathrm{kg}$ for the ROK 16 rice husk, $16.607 \mathrm{MJ} / \mathrm{kg}$ for the ROK 32 rice husk, $15.262 \mathrm{MJ} / \mathrm{kg}$ for the CP 4 rice husk and $16.068 \mathrm{MJ} / \mathrm{kg}$ for the Pa Potho rice husk. 
Yaning Zhang et al. / American Journal of Engineering and Applied Sciences 6 (2): 216-225, 2013

Table 2. Mineral oxide compositions of rice husks (Mansaray and Ghaly, 1997)

\begin{tabular}{|c|c|c|c|c|c|c|}
\hline \multirow{2}{*}{ Mineral oxide } & \multicolumn{6}{|c|}{ Mineral oxide composition (mol per kg of rice husk) } \\
\hline & Lemont & ROK 14 & ROK 16 & ROK 32 & CP 4 & Pa Potho \\
\hline $\mathrm{SiO}_{2}$ & 3.3992 & 2.6858 & 2.0982 & 2.5154 & 3.3532 & 2.6397 \\
\hline $\mathrm{K}_{2} \mathrm{O}$ & 0.0474 & 0.0419 & 0.0364 & 0.0499 & 0.0475 & 0.0312 \\
\hline $\mathrm{CaO}$ & 0.0182 & 0.0181 & 0.0489 & 0.0135 & 0.0136 & 0.0096 \\
\hline $\mathrm{P}_{2} \mathrm{O}_{5}$ & 0.0088 & 0.0069 & 0.0116 & 0.0105 & 0.0095 & 0.0003 \\
\hline $\mathrm{MgO}$ & 0.0232 & 0.0175 & 0.0136 & 0.0187 & 0.0167 & 0.0122 \\
\hline $\mathrm{Al}_{2} \mathrm{O}_{3}$ & 0.0010 & 0.0019 & 0.0034 & 0.0021 & 0.0020 & 0.0021 \\
\hline $\mathrm{Fe}_{2} \mathrm{O}_{3}$ & 0.0012 & 0.0011 & 0.0023 & 0.0014 & 0.0013 & 0.0016 \\
\hline $\mathrm{Na}_{2} \mathrm{O}$ & 0.0027 & 0.0064 & 0.0020 & 0.0062 & 0.0011 & 0.0021 \\
\hline $\mathrm{SO}_{3}$ & 0.0027 & 0.0189 & 0.0185 & 0.0231 & 0.0313 & 0.0022 \\
\hline $\mathrm{TiO}_{2}$ & 0.0009 & 0.0009 & 0.0007 & 0.0011 & 0.0017 & 0.0004 \\
\hline $\mathrm{ZnO}$ & 0.0002 & 0.0002 & 0.0003 & 0.0002 & 0.0002 & 0.0002 \\
\hline
\end{tabular}

Table 3. S, C, O, H and N contents of rice husks (Mansaray and Ghaly, 1997)

\begin{tabular}{lccccc}
\hline Rice husk & $\mathrm{C}$ & $\mathrm{H}$ & $\mathrm{O}$ & $\mathrm{N}$ & $\mathrm{S}$ \\
\hline Lemont & 34.186 & 4.928 & 30.185 & 0.345 & 0.031 \\
ROK 14 & 38.446 & 4.548 & 30.775 & 0.365 & 0.022 \\
ROK 16 & 39.854 & 4.935 & 31.525 & 0.412 & 0.019 \\
ROK 32 & 37.985 & 4.445 & 30.173 & 0.413 & 0.013 \\
CP 4 & 35.217 & 4.277 & 28.665 & 0.455 & 0.014 \\
Pa Potho & 38.272 & 4.582 & 30.186 & 0.458 & 0.022 \\
\hline
\end{tabular}

Values are in units of wt.\%, on as received basis

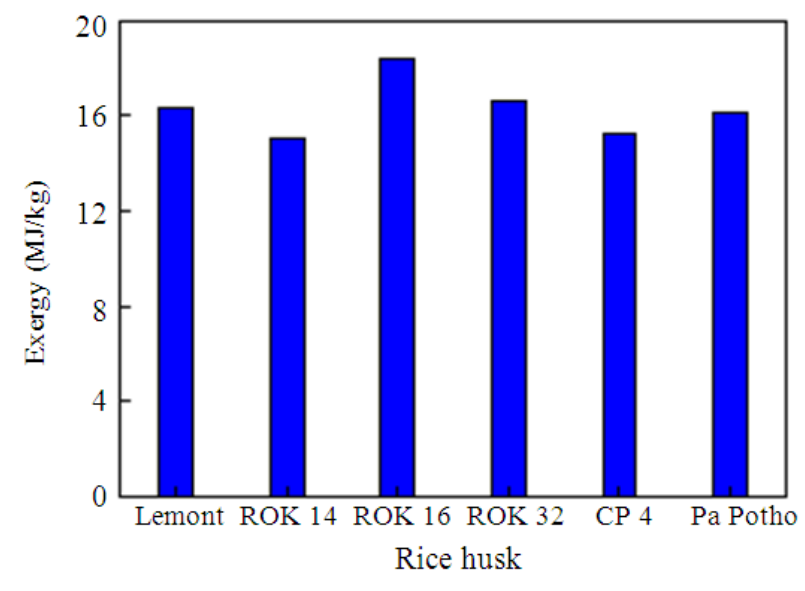

Fig. 1. Exergy values of rice husks.

The ROK 16 rice husk had the highest exergy value $(18.407 \mathrm{MJ} / \mathrm{kg})$ whereas the ROK 14 rice husk had the lowest exergy value $(15.053 \mathrm{MJ} / \mathrm{kg})$. These values (15.053-18.407 MJ/kg) are lower than the exergy values (21.04-38.88 MJ/kg) of coals reported by Bilgen et al. (2004) due to their heating values $(18.70-36.73 \mathrm{MJ} / \mathrm{kg})$.

\subsection{Effect of LHV}

Equation 1 shows that the exergy of a fuel depends on the LHV of the fuel. The higher LHV of a fuel the higher exergy of the fuel. In this study, a positive linear relationship between exergy value and LHV was observed as shown in Fig. 2. The relationship can be described by the following linear Equation $8\left(\mathrm{R}^{2}=\right.$ 0.998):

$\mathrm{ex}=0.164+1.127$ LHV $(13.24 \leq \mathrm{LHV} \leq 16.20)$

Bilgen et al. (2004) stated that the exergy value of coal varies proportionally with the heating value. Bilgen and Kaygusuz (2008) used the HHVs to calculate the exergy of coals. Hosseini et al. (2012) and Hepbasli (2008) used the LHVs to calculate the exergy of biomass fuels. In this study, a positive linear relationship between exergy value and LHV was observed for biomass fuel (rice husk). Both exergy value and heating value therefore can be used to evaluate a kind of fuel.

\subsection{Effect of Moisture Content.}

The moisture related exergy was detailed in this study. The moisture related exergy value was 254.534 $\mathrm{kJ} / \mathrm{Kg}$ for the Lemont rice husk, $241.432 \mathrm{~kJ} / \mathrm{kg}$ for the ROK 14 rice husk, $290.304 \mathrm{~kJ} / \mathrm{kg}$ for the ROK 16 rice husk, $283.574 \mathrm{~kJ} / \mathrm{kg}$ for the ROK 32 rice husk, $250.681 \mathrm{~kJ} / \mathrm{kg}$ for the CP 4 rice husk and 282.412 $\mathrm{kJ} / \mathrm{kg}$ for the $\mathrm{Pa}$ Potho rice husk. 
It can be seen from Eq. 1 that the moisture related exergy value is proportional to the moisture content of biomass fuel. The ROK 16 rice husk had the highest moisture content $(10.44 \%)$ and the highest moisture related exergy value $(290.304 \mathrm{~kJ} / \mathrm{kg})$ whereas the ROK 14 rice husk had the lowest moisture content $(8.68 \%)$ and the lowest moisture related exergy value (241.432 $\mathrm{kJ} / \mathrm{kg}$ ). In this study, an exponential relationship between exergy value (of rice husk) and moisture content was observed as shown in Fig. 3. The relationship can be described by the following exponential Equation $9\left(\mathrm{R}^{2}=0.772\right)$ :

$e x=15.466+1.274 \times 10^{-18} \exp (-\mathrm{M} /-0.247) \quad(8.68 \leq \mathrm{M} \leq 10.44)$

Where:

$\mathrm{M} \quad$ is the moisture content (\%)

Bilgen and Kaygusuz (2008) and Song et al. (2012) stated that the contribution of moisture content to the exergy of coal and biomass is negligible because the change in exergy due to moisture content is quite small compared with the total exergy of the fuel. In this study, an exponential relationship between exergy value and moisture content was observed for biomass. Increasing the moisture content from $8.68 \%$ to $10.44 \%$ increased the exergy of rice husk from $15.053 \mathrm{MJ} / \mathrm{kg}$ to $18.407 \mathrm{MJ} / \mathrm{kg}$. However, the moisture content of biomass can substantially affect its quality as a fuel source (Zhang et al., 2012). Mansaray and Ghaly (1997) and Chen et al. (2009) reported that an increase in moisture content of the rice residues decreased their heating value, which in turn reduced the conversion efficiency and performance of the system. A dry material is thus preferred for storage and combustion (Zhang et al., 2012).

\subsection{Effect of Ash}

The exergy values of mineral oxides $\left(\mathrm{SiO}_{2}, \mathrm{~K}_{2} \mathrm{O}\right.$, $\mathrm{CaO}, \mathrm{P}_{2} \mathrm{O}_{5}, \mathrm{MgO}, \mathrm{Al}_{2} \mathrm{O}_{3}, \mathrm{Fe}_{2} \mathrm{O}_{3}, \mathrm{Na}_{2} \mathrm{O}, \mathrm{SO}_{3}, \mathrm{TiO}_{2}$ and $\mathrm{ZnO}$ ) are presented in Table 4. Based on the exergy values of mineral oxides and the ash compositions of rice husks (Table 2), the values and fractions of exergy of mineral oxide compositions were obtained for different rice husks as shown in Table 5. $\mathrm{SiO}_{2}, \mathrm{~K}_{2} \mathrm{O}, \mathrm{CaO}, \mathrm{MgO}$, $\mathrm{SO}_{3}, \quad \mathrm{Na}_{2} \mathrm{O}, \quad \mathrm{P}_{2} \mathrm{O}_{5}, \quad \mathrm{Al}_{2} \mathrm{O}_{3}, \quad \mathrm{Fe}_{2} \mathrm{O}_{3}, \quad \mathrm{TiO}_{2}$ and $\mathrm{ZnO}$ contributed $\quad 34.105-55.728 \%, \quad 30.912-37.054 \%$, $2.444-11.080 \%, \quad 1.818-2.801 \%, \quad 1.195-12.743 \%$, $0.524-3.662 \%, \quad 0.382-9.837 \%, \quad 0.377-1.385 \%$, $0.034-0.078 \%, 0.024-0.059 \%$ and $0.007-0.017 \%$ to the exergy values of ash, respectively.

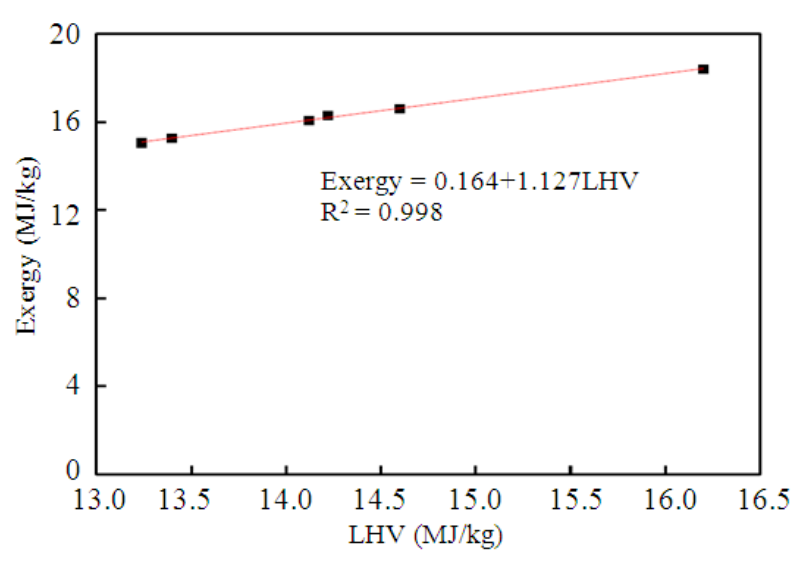

Fig. 2. Relationship between exergy value and LHV

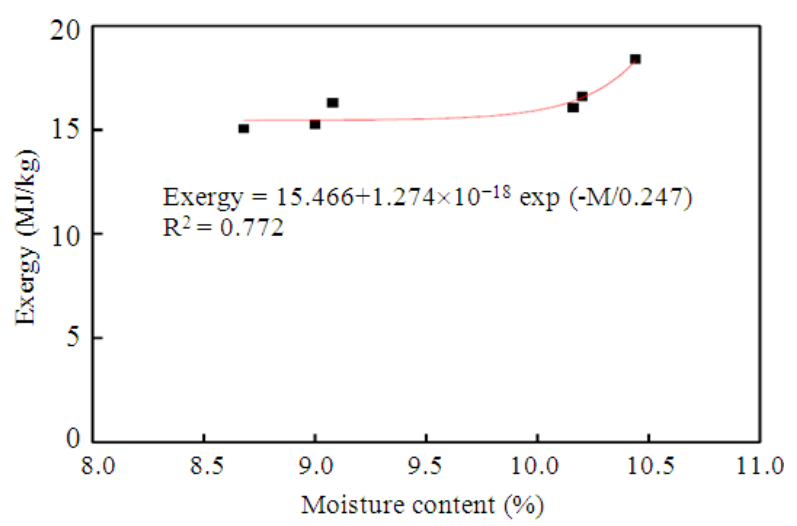

Fig. 3. Relationship between exergy value and moisture content

Although $\mathrm{SiO}_{2}$ had the lowest exergy value (7.9 $\mathrm{kJ} / \mathrm{mol})$, it contributed the most (34.105-55.728\%) to the exergy values of ash for all the rice husk varieties. This was due to the fact that $\mathrm{SiO}_{2}$ was the main component of the ash. The weight fraction of $\mathrm{SiO}_{2}$ reported by Mansaray and Ghaly (1997) ranged from 90\% (ROK 32 and $\mathrm{CP} 4$ ) to $97 \%$ (Pa Potho).

The total exergy value was $55.382 \mathrm{~kJ} / \mathrm{kg}$ for the Lemont rice husk ash, $51.535 \mathrm{~kJ} / \mathrm{kg}$ for the ROK 14 rice husk ash, $48.600 \mathrm{~kJ} / \mathrm{kg}$ for the ROK 16 rice husk ash, $55.646 \mathrm{~kJ} / \mathrm{kg}$ for the ROK 32 rice husk ash, $61.217 \mathrm{~kJ} / \mathrm{kg}$ for the CP 4 rice husk ash and 37.419 $\mathrm{kJ} / \mathrm{kg}$ for the Pa Potho rice husk ash. The $\mathrm{CP} 4$ rice husk ash had the highest exergy $(61.217 \mathrm{~kJ} / \mathrm{kg})$ whereas the $\mathrm{Pa}$ Potho rice husk ash had the lowest exergy $(37.419 \mathrm{~kJ} / \mathrm{kg})$. This did not agree with the ash contents of rice husks (Table 1) where the CP 4 rice husk had the highest ash content $(22.386 \%)$ and the ROK 16 rice husk had the lowest ash content (13.703\%). 
Table 4. Exergy values of mineral oxides (Szargut et al., 1988)

\begin{tabular}{lc}
\hline $\mathrm{Mineral}$ oxide & Exergy value $(\mathrm{kJ} / \mathrm{mol})$ \\
\hline $\mathrm{SiO}_{2}$ & 7.90 \\
$\mathrm{~K}_{2} \mathrm{O}$ & 413.10 \\
$\mathrm{CaO}$ & 110.20 \\
$\mathrm{P}_{2} \mathrm{O}_{5}$ & 412.65 \\
$\mathrm{MgO}$ & 66.80 \\
$\mathrm{Al}_{2} \mathrm{O}_{3}$ & 200.40 \\
$\mathrm{Fe}_{2} \mathrm{O}_{3}$ & 16.50 \\
$\mathrm{Na}_{2} \mathrm{O}$ & 296.20 \\
$\mathrm{SO}_{3}$ & 249.10 \\
$\mathrm{TiO}_{2}$ & 21.40 \\
$\mathrm{ZnO}$ & 22.90 \\
\hline
\end{tabular}

This shows that the exergy of ash is not only determined by the ash content but also by the ash composition.

An exponential relationship between exergy value (of rice husk) and ash content was observed as shown in Fig. 4. The relationship can be described by the following exponential Equation $10\left(\mathrm{R}^{2}=0.616\right)$ :

$\mathrm{ex}=15.685+83001.827 \exp (-\mathrm{A} / 1.327)(13.703 \leq \mathrm{A} \leq 22.386)(10)$

Where:

A is the ash content (\%)

Hepbasli (2008) and Szargut et al. (1988) stated that the exergy of ash can usually be neglected because the change in total exergy of fuel due to the change in ash content is very small. However, Song et al. (2012) estimated the exergy of solid and liquid fuels and reported decreases in exergy when the ash content increased. On the other hand, higher ash content can reduce the heating value of a fuel and cause agglomeration for a system (Vargas-Moreno et al., 2012; Zhao et al., 2012). Lower ash content fuels are therefore preferred.

\subsection{Effects of $S$}

The $\mathrm{S}$ related exergy value was also detailed in this study. The S related exergy value was $2.993 \mathrm{~kJ} / \mathrm{kg}$ for the Lemont rice husk, $2.122 \mathrm{~kJ} / \mathrm{kg}$ for the ROK 14 rice husk, $1.821 \mathrm{~kJ} / \mathrm{kg}$ for the ROK 16 rice husk, $1.217 \mathrm{~kJ} / \mathrm{kg}$ for the ROK 32 rice husk, $1.322 \mathrm{~kJ} / \mathrm{kg}$ for the $\mathrm{CP} 4$ rice husk and $2.175 \mathrm{~kJ} / \mathrm{kg}$ for the Pa Potho rice husk. These values were directly determined by the weight fractions of $\mathrm{S}$ (Table 3), which can be easily seen from Eq. 1. In Table 3, the Lemont rice husk had the highest $\mathrm{S}$ content $(0.031 \%)$ whereas the ROK 32 rice husk had the lowest S content $(0.013 \%)$, leading to the result that the Lemont rice husk had the highest $\mathrm{S}$ related exergy value $(2.993$ $\mathrm{kJ} / \mathrm{kg}$ ) whereas the ROK 32 rice husk had the lowest $\mathrm{S}$ related exergy value $(1.217 \mathrm{~kJ} / \mathrm{kg})$.

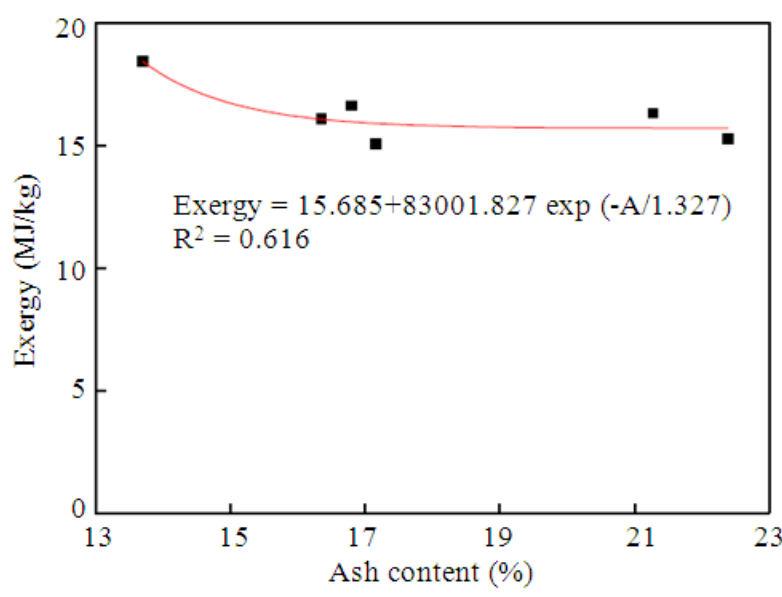

Fig. 4. Relationship between exergy value and ash content

Bilgen et al. (2004) calculated the exergy of coals and reported increases in exergy when $\mathrm{S}$ content increased. Govin et al. (2000) estimated the exergy of liq uid sub stances and reported decreases in exergy when $\mathrm{S}$ content increased. However, it appears from the results of this study that the $\mathrm{S}$ content did not have significant effect on the exergy of rice husk. While the S content varied from $0.013 \%$ to $0.031 \%(138.462 \%)$, the exergy of rice husks fluctuated between $15.053 \mathrm{MJ} / \mathrm{kg}$ and $18.407 \mathrm{MJ} / \mathrm{kg}(22.281 \%)$ without any clear trend.

\subsection{Exergy Distribution}

The percentages of moisture related exergy, ash exergy and S related exergy are shown in Table 6. The percentage of moisture related exergy is defined as the moisture related exergy divided by the exergy of rice husk. It indicates the fraction of the moisture related exergy in the total exergy of rice husk. The percentage of moisture related exergy was $1.563 \%$ for the Lemont rice husk, $1.604 \%$ for the ROK 14 rice husk, $1.577 \%$ for theROK 16 rice husk, $1.708 \%$ for the ROK 32 rice husk, $1.642 \%$ for the CP 4 rice husk and $1.758 \%$ for the $\mathrm{Pa}$ Potho rice husk. These values were determined by the exergy values of rice husks and the moisture related exergy values. The percentages of moisture related exergy were between $1.563 \%$ and $1.758 \%$, indicating that the moisture related exergy $(241.432-290.304 \mathrm{~kJ} / \mathrm{kg})$ was a small part of the exergy (15.053-18.407 MJ/kg) of rice husks.

The percentage of ash exergy is defined as the exergy of ash divided by the exergy of rice husk. It representsthe fraction of the ash exergy in the total exergy of rice husk. 
Table 5. Values and fractions of exergy of mineral oxide compositions.

\begin{tabular}{|c|c|c|c|c|c|c|c|c|c|c|c|c|}
\hline \multirow{3}{*}{$\begin{array}{l}\text { Mineral } \\
\text { oxide }\end{array}$} & \multicolumn{12}{|c|}{ Values and fractions } \\
\hline & \multicolumn{2}{|c|}{ Lemont } & \multicolumn{2}{|c|}{ ROK 14} & \multicolumn{2}{|c|}{ ROK 16} & \multicolumn{2}{|c|}{ ROK 32} & \multicolumn{2}{|c|}{ CP 4} & \multicolumn{2}{|c|}{ Pa Potho } \\
\hline & $\begin{array}{c}\text { Value } \\
(\mathrm{kJ} / \mathrm{kg})\end{array}$ & $\begin{array}{c}\text { Fraction } \\
(\%)\end{array}$ & $\begin{array}{c}\text { Value } \\
(\mathrm{kJ} / \mathrm{kg})\end{array}$ & $\begin{array}{c}\text { Fraction } \\
(\%)\end{array}$ & $\begin{array}{c}\text { Value } \\
(\mathrm{kJ} / \mathrm{kg})\end{array}$ & $\begin{array}{c}\text { Fraction } \\
(\%)\end{array}$ & $\begin{array}{c}\text { Value } \\
(\mathrm{kJ} / \mathrm{kg})\end{array}$ & $\begin{array}{c}\text { Fraction } \\
(\%)\end{array}$ & $\begin{array}{c}\text { Value } \\
(\mathrm{kJ} / \mathrm{kg})\end{array}$ & $\begin{array}{c}\text { Fraction } \\
(\%)\end{array}$ & $\begin{array}{c}\text { Value } \\
(\mathrm{kJ} / \mathrm{kg})\end{array}$ & $\begin{array}{c}\text { Fraction } \\
(\%)\end{array}$ \\
\hline $\mathrm{SiO}_{2}$ & 26.854 & 48.489 & 21.218 & 41.172 & 16.575 & 34.105 & 19.872 & 35.711 & 26.490 & 43.272 & 20.853 & 55.728 \\
\hline $\mathrm{K}_{2} \mathrm{O}$ & 19.592 & 35.376 & 17.316 & 33.600 & 15.023 & 30.912 & 20.619 & 37.054 & 19.634 & 32.073 & 12.907 & 34.493 \\
\hline $\mathrm{CaO}$ & 2.007 & 3.624 & 1.990 & 3.861 & 5.385 & 11.080 & 1.485 & 2.669 & 1.496 & 2.444 & 1.060 & 2.833 \\
\hline $\mathrm{P}_{2} \mathrm{O}_{5}$ & 3.649 & 6.589 & 2.845 & 5.521 & 4.781 & 9.837 & 4.345 & 7.808 & 3.905 & 6.379 & 0.143 & 0.382 \\
\hline $\mathrm{MgO}$ & 1.551 & 2.801 & 1.166 & 2.263 & 0.908 & 1.868 & 1.252 & 2.250 & 1.113 & 1.818 & 0.813 & 2.173 \\
\hline $\mathrm{Al}_{2} \mathrm{O}_{3}$ & 0.209 & 0.377 & 0.371 & 0.720 & 0.673 & 1.385 & 0.429 & 0.771 & 0.396 & 0.647 & 0.418 & 1.117 \\
\hline $\mathrm{Fe}_{2} \mathrm{O}_{3}$ & 0.020 & 0.036 & 0.018 & 0.035 & 0.038 & 0.078 & 0.023 & 0.041 & 0.021 & 0.034 & 0.027 & 0.072 \\
\hline $\mathrm{Na}_{2} \mathrm{O}$ & 0.813 & 1.468 & 1.887 & 3.662 & 0.589 & 1.212 & 1.846 & 3.317 & 0.321 & 0.524 & 0.625 & 1.670 \\
\hline $\mathrm{SO}_{3}$ & 0.662 & 1.195 & 4.701 & 9.122 & 4.605 & 9.475 & 5.747 & 10.328 & 7.801 & 12.743 & 0.560 & 1.497 \\
\hline $\mathrm{TiO}_{2}$ & 0.020 & 0.036 & 0.018 & 0.035 & 0.015 & 0.031 & 0.023 & 0.041 & 0.036 & 0.059 & 0.009 & 0.024 \\
\hline $\mathrm{ZnO}$ & 0.005 & 0.009 & 0.005 & 0.009 & 0.008 & 0.017 & 0.005 & 0.010 & 0.004 & 0.007 & 0.004 & 0.011 \\
\hline Total & 55.382 & 100 & 51.535 & 100 & 48.600 & 100 & 55.646 & 100 & 61.217 & 100 & 37.419 & 100 \\
\hline
\end{tabular}

Table 6. Percentages of moisture, ash and S related exergy.

\begin{tabular}{lcccc}
\hline \multirow{2}{*}{ Rice husk } & \multicolumn{4}{c}{ Percentage (\%) } \\
\cline { 2 - 5 } & Moisture & Ash & S & Total \\
\hline Lemont & 1.563 & 0.340 & 0.018 & 1.921 \\
ROK 14 & 1.604 & 0.342 & 0.014 & 1.960 \\
ROK 16 & 1.577 & 0.264 & 0.010 & 1.851 \\
ROK 32 & 1.708 & 0.335 & 0.007 & 2.050 \\
CP 4 & 1.642 & 0.401 & 0.009 & 2.052 \\
Pa Potho & 1.758 & 0.233 & 0.014 & 2.005 \\
\hline
\end{tabular}

The percentage of ash exergy was $0.340 \%$ for the Lemont rice husk, $0.342 \%$ for the ROK 14 rice husk, $0.264 \%$ for the ROK 16 rice husk, $0.335 \%$ for the ROK 32 rice husk, $0.401 \%$ for the CP 4 rice husk and $0.233 \%$ for the $\mathrm{Pa}$ Potho rice husk. The percentage of ash exergy ranged from $0.233 \%$ (Pa Potho rice husk) to $0.401 \%$ (CP 4 rice husk), being very small amounts.

The percentage of $\mathrm{S}$ related exergy is defined as $\mathrm{S}$ related exergy divided by the exergy of rice husk. It indicates the fraction of the $\mathrm{S}$ related exergy in the total exergy of rice husk. The percentage of S related exergy was $0.018 \%$ for the Lemont rice husk, $0.014 \%$ for the ROK 14 rice husk, $0.010 \%$ for the ROK 16 rice husk, $0.007 \%$ for the ROK 32 rice husk, $0.009 \%$ for the CP 4 rice husk and $0.014 \%$ for the Pa Potho rice husk. These values were mainly determined by the $\mathrm{S}$ related exergy values. The Lemont rice husk had the highest $\mathrm{S}$ related exergy value $(2.993 \mathrm{~kJ} / \mathrm{kg})$ whereas the ROK 32 rice husk had the lowest $\mathrm{S}$ related exergy value $(1.217 \mathrm{~kJ} / \mathrm{kg})$, resulting in the fact that the Lemont rice husk had the highest percentage of S related exergy $(0.018 \%)$ whereas the ROK 32 rice husk had the lowest percentage of $\mathrm{S}$ related exergy $(0.007 \%)$. These values ranged in $0.007-0.018 \%$, therefore can be neglected.
Song et al. (2012) stated that exergies of ash and inorganic matter for both solid and liquid fuels could be ignored. In our present study, the moisture related exergy, ash exergy and $\mathrm{S}$ related exergy accounted for $1.563-1.758 \%, 0.233-0.401 \%$ and $0.007-0.018 \%$ of the exergy of rice husks, respectively, making up $1.851-2.052 \%$ collectively. The exergy values of the six rice husks were therefore determined by the LHVs and the correlation factors. In some studies (Hosseini et al., 2012; Hepbasli, 2008; Zhang et al., 2011), the exergy of biomass was even derived directly from the product of LHV and correlation factor.

\subsection{The Correlation Factor $(\beta)$}

The effects of $\mathrm{C}, \mathrm{O}, \mathrm{H}$ and $\mathrm{N}$ can be demonstrated by studying the correlation factors. Based on the $\mathrm{C}, \mathrm{O}$, $\mathrm{H}$ and $\mathrm{N}$ contents (Table 3 ), the $\mathrm{C}, \mathrm{H}, \mathrm{O}$ and $\mathrm{N}$ atomic structure was determined as shown in Table 7. The numbers of $\mathrm{C}, \mathrm{H}$ and $\mathrm{O}$ atoms varied among the various rice husks. For every atom of $\mathrm{N}$, the rice husks contained 90-123 atoms of C, 132-200 atoms of $\mathrm{H}$ and 55-77 atoms of $\mathrm{O}$. The $\mathrm{O} / \mathrm{C}, \mathrm{H} / \mathrm{C}$ and $\mathrm{N} / \mathrm{C}$ atomic ratios are shown in Table 8 . The $\mathrm{O} / \mathrm{C}$ atomic ratio was 0.662 for the Lemontrice husk, 0.600 for the ROK 14 rice husk, 0.593 for the ROK 16 rice husk, 0.596 for the ROK 32 rice husk, 0.610 for the CP 4 rice husk and 0.592 for the $\mathrm{Pa}$ Potho rice husk. These values (0.592-0.662) were higher than 0.5. Therefore, Eq. 6 was selected for determination of the correlation factors.

Figure 5 shows the correlation factors of the six rice husks. The correlation factor was 1.127 for the Lemont rice husk, 1.119 for the ROK 14 rice husk, 1.118 for the ROK 16 rice husk, 1.118 for the ROK 32 rice husk, 1.120 for the $\mathrm{CP} 4$ rice husk and 1.118 for the Pa Potho rice husk. 
Table 7. C, H, O and $\mathrm{N}$ atomic structure of rice husks.

\begin{tabular}{lccccc}
\hline \multirow{2}{*}{ Rice husk } & \multicolumn{2}{c}{ Atomic structure } & Molecular structure \\
\cline { 2 - 4 } & $\mathrm{C}$ & $\mathrm{H}$ & $\mathrm{O}$ & $\mathrm{N}$ & \\
\hline Lemont & 116 & 174 & 77 & 1 & $\mathrm{C}_{116} \mathrm{H}_{200} \mathrm{O}_{77} \mathrm{~N}$ \\
ROK 14 & 123 & 168 & 67 & 1 & $\mathrm{C}_{123} \mathrm{H}_{174} \mathrm{O}_{74} \mathrm{~N}$ \\
ROK 16 & 113 & 151 & 64 & 1 & $\mathrm{C}_{113} \mathrm{H}_{168} \mathrm{O}_{67} \mathrm{~N}$ \\
ROK 32 & 107 & 132 & 55 & 1 & $\mathrm{C}_{107} \mathrm{H}_{151} \mathrm{O}_{64} \mathrm{~N}$ \\
CP 4 & 90 & 140 & 58 & 1 & $\mathrm{C}_{90} \mathrm{H}_{132} \mathrm{O}_{55} \mathrm{~N}$ \\
Pa Potho & 97 & & 1 & $\mathrm{C}_{97} \mathrm{H}_{140} \mathrm{O}_{58} \mathrm{~N}$ \\
\hline
\end{tabular}

$\underline{\text { Table 8. } \mathrm{O} / \mathrm{C}, \mathrm{H} / \mathrm{C} \text { and } \mathrm{N} / \mathrm{C} \text { atomic ratios of rice husks. }}$

\begin{tabular}{lccc}
\hline \multirow{2}{*}{ Rice husk } & \multicolumn{1}{c}{ Atomic ratios } & N/C \\
\cline { 2 - 4 } & $\mathrm{O} / \mathrm{C}$ & $\mathrm{H} / \mathrm{C}$ & 0.009 \\
Lemont & 0.662 & 1.730 & 0.008 \\
ROK 14 & 0.600 & 1.420 & 0.009 \\
ROK 16 & 0.593 & 1.486 & 0.009 \\
ROK 32 & 0.596 & 1.404 & 0.011 \\
CP 4 & 0.610 & 1.457 & 0.010 \\
Pa Potho & 0.592 & 1.437 & \\
\hline
\end{tabular}

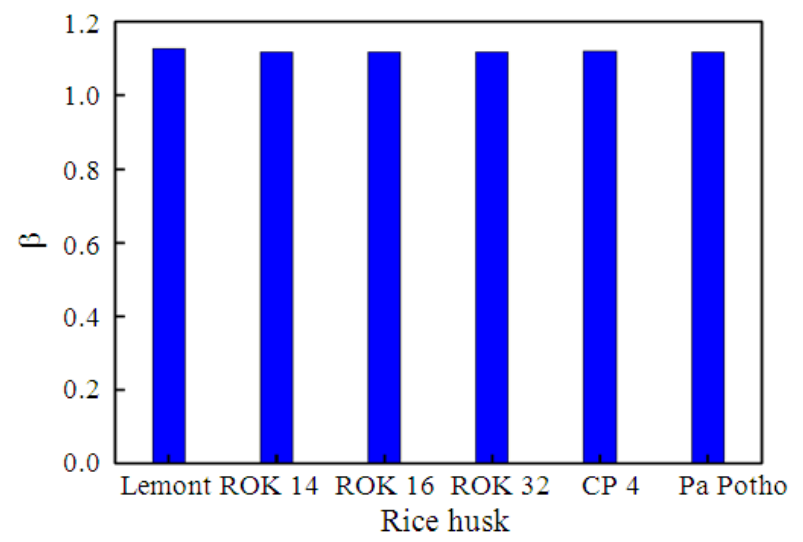

Fig. 5. Correlation factors of rice husks

Similar results were also reported by various researches. The correlation factors between exergy values and HHVs reported by Bilgen et al. (2004) ranged in 1.0587-1.1260 for coals. The correlation factors between exergy values and LHVs reported by Zhang et al. (2011) varied in 1.05-1.19 for biomass fuels. Nilsson (1997) reported the correlation factor between exergy value and LHV was 1.16 for a moist straw.

Although the $\mathrm{O} / \mathrm{C}, \mathrm{H} / \mathrm{C}$ and $\mathrm{N} / \mathrm{C}$ atomic ratios varied in ranges of $0.592-0.662 \quad(11.82 \%), \quad 1.404-1.730$ $(23.22 \%)$ and $0.008-0.011(37.50 \%)$, respectively, the correlation factors varied slightly in the range of1.118-1.127 (0.008\%). These values are more concentrated than the values $(1.0587-1.1260)$ of coals reported by Bilgen et al. (2004) and the values (1.05-1.19) of biomass fuels reported by Zhang et al. (2011).

\section{CONCLUSION}

The exergy values of the six rice husks were investigated and the effects of moisture content, ash content, S, C, O, H and $\mathrm{N}$ contents were also studied. The following conclusions can be obtained. The moisture related exergy of the six rice husks ranged between $241.432 \mathrm{~kJ} / \mathrm{kg}$ (ROK 14) and $290.304 \mathrm{~kJ} / \mathrm{kg}$ (ROK 16), accounting for $1.563-1.758 \%$ of the exergy of rice husks. An exponential relationship between exergy value and moisture content was observed. The exergy of ash varied between $37.419 \mathrm{~kJ} / \mathrm{kg}$ (Pa Potho) and $61.217 \mathrm{~kJ} / \mathrm{kg}$ (CP 4), making up $0.233-0.401 \%$ of the exergy of rice husks. An exponential relationship between exergy value and ash content was observed. The $\mathrm{S}$ related exergy ranged from $1.217 \mathrm{~kJ} / \mathrm{kg}$ (ROK 32) to $2.993 \mathrm{~kJ} / \mathrm{kg}$ (Lemont), accounting for $0.007-0.018 \%$ of the exergy of rice husks. The $\mathrm{O} / \mathrm{C}, \mathrm{H} / \mathrm{C}$ and $\mathrm{N} / \mathrm{C}$ atomic ratios varied in ranges of $0.592-0.662,1.404-1.730$ and $0.008-0.011$, respectively, whereas the correlation factors varied slightly in the range of 1.118-1.127. The exergy values of the six rice husks were between $15.053 \mathrm{MJ} / \mathrm{kg}$ (ROK 14) and 18.407 $\mathrm{MJ} / \mathrm{kg}$ (ROK 16). They were mainly determined by the correlation factors and the LHVs. A positive linear relationship between exergy value and LHV was observed.

\section{ACKOWLEDGEMENTS}

The project was funded by National Science and Engineering Council (NSERC) of Canada. 


\section{REFERENCES}

Bilgen, S. and K. Kaygusuz, 2008. The calculation of the chemical exergies of coal-based fuels by using the higher heating values. Applied Energy, 85: 776-785. DOI: 10.1016/j.apenergy.2008.02.001

Bilgen, S., K. Kaygusuz and A. Sari, 2004. Second law analysis of various types of coal and woody biomass in Turkey. Energy Sources, 26: 1083-1094. DOI: $10.1080 / 00908310490494621$

Chen, L., L. Xing and L. Han, 2009. Renewable energy from agro-residues in China: Solid biofuels and biomass briquetting technology. Renewable and Sustainable Energy Reviews, 13: 2689-2695. DOI: 10.1016/j.rser.2009.06.025

Dincer, I., 2002. The role of exergy in energy policy making. Energy Policy, 30: 137-149. DOI: 10.1016/S0301-4215(01)00079-9

FAO, 2011. Rice Market Monitor.

Ghaly, A.E. and A. Al-taweel, 1990. Physical and thermochemical properties of cereal straws. Energy Sources, 12: 131-145. DOI: 10.1080/00908319008960195.

Govin, O. V., V. V. Diky, G. J. Kabo and A. V. Blokhin, 2000. Evaluation of the chemical exergy of fuels and petroleum fractions. J. Thermal Analysis Calorimetry, 62: 123-133. DOI: 10.1023/A:1010166812761

Hepbasli, A., 2008. A key review on exergetic analysis and assessment of renewable energy resources for a sustainable future. Renewable Sustainable Energy Rev., 12: 593-661. DOI: 10.1016/j.rser.2006.10.001

Hosseini, M., I. Dincer and M. A. Rosen, 2012. Steam and air fed biomass gasification: Comparisons based on energy and exergy. Int. J. Hydrogen Energy, 37: 16446-16452. DOI: 10.1016/j.ijhydene.2012.02.115

Kaewkhao, J. and P. Limsuwan, 2012. Utilization of rice husk fly ash in the color glass production. Proc. Eng., 32 : 670-675. DOI: 10.1016/j.proeng.2012.01.1325

Kuo, H.P., S.M. Pan and H.T. Hsu, 2011. Comparisons of the hydrogen-rich syngas compositions from wet rice husk slurry steamreforming reactions using different catalysts. Biomass Bioenergy, 35: 3025-3031. DOI: 10.1016/j.biombioe.2011.04.005

Lu, Y., X. Wei, J. Cao, P. Li, F. Liu, Y. Zhao, X. Fan, W. Zhao, L. Rong, Y. Wei, S.Wang, J. Zhou and Z. Zong, 2012. Characterization of a bio-oil from pyrolysis of rice husk by detailed compositional analysis and structural investigation of lignin. Bioresource Technol., 116: 114-119. DOI: 10.1016/j.biortech.2012.04.006
Mansaray, K.G. and A. E. Ghaly, 1997. Physical and thermochemical properties of rice husk. Energy Sources, 19: 989-1004. DOI: 10.1080/00908319708908904

Martínez, J. D., T. Pineda, J. P. López and M. Betancur, 2011. Assessment of the rice husk lean-combustion in a bubbling fluidized bed for the production of amorphous silica-rich ash. Energy, 36: 3846-3854. DOI: 10.1016/j.energy.2010.07.031

Moran, M. J., H. N. Shapiro, D. D. Boettner and M. B. Bailey, 2011. Fundamentals of engineering thermodynamics. 7th Edn., John Wiley and Sons, Inc.

Nilsson, D., 1997. Energy, exergy and emergy analysis of using straw as fuel in district heating plants. Biomass and Bioenergy, 13: 63-73. DOI: 10.1016/S0961-9534(97)00025-1

Reidy, S., 2011. Global Rice Science Partnership seeks to increase productivity, improve efficiency of world staple crop.

Rosen, M.A. and C.A. Bulucea, 2009. Using Exergy to Understand and Improve the Efficiency of Electrical Power Technologies. Entropy, 11: 820-835. DOI: 10.3390/e11040820.

Shen, J., S. Zhu, X. Liu, H. Zhang and J. Tan, 2012. Measurement of Heating Value of Rice Husk by Using Oxygen Bomb Calorimeter with Benzoic Acid as Combustion Adjuvant. Energy Procedia, 17: 208-213. DOI: 10.1016/j.egypro.2012.02.085

Shirai, H., M. Ikeda and H. Aramaki, 2012. Characteristics of hydrogen sulfide formation in pulverized coal combustion. Fuel (in press). DOI: 10.1016/j.fuel.2012.03.028

Singha, B. and S. K. Das, 2011. Biosorption of Cr (VI) ions from aqueous solutions: Kinetics, equilibrium, thermodynamics and desorption studies. Colloids and Surfaces B: Biointerfaces, 84: 221-232. DOI: 10.1016/j.colsurfb.2011.01.004.

Soest, P.J.V., 2006. Rice straw, the role of silica and treatments to improve quality. Animal Feed Sci. Technol., 130: 137-171. DOI: 10.1016/j.anifeedsci.2006.01.023.

Song, G., J. Xiao, H. Zhao and L. Shen, 2012. A unified correlation for estimating specific chemical exergy of solid and liquid fuels. Energy, 40: 164-173. DOI: 10.1016/j.energy.2012.02.016.

Szargut, J., 1980. International progress in second law analysis. Energy, 5: 709-718. DOI: 10.1016/0360-5442(80)90090-0.

Szargut, J., D.R. Morris and F.R. Stewart, 1988. Exergy analysis of thermal, chemical and metallurgical processes. Edwards Brothers, Inc. 
Vadiveloo, J., B. Nurfariza and J.G. Fadel, 2009. Nutritional improvement of rice husks. Animal Feed Sci. Technol., 151: 299-305. DOI: 10.1016/j.anifeedsci.2009.03.002

Vargas-Moreno, J.M., A.J. Callejón-Ferre, J. Pérez-Alonso and B. Velázquez-Martí, 2012. A review of the mathematical models for predicting the heating value of biomass materials. Renewable and Sustainable Energy Rev., 16: 3065-3083. DOI: 10.1016/j.rser.2012.02.054

Wall, G., 1986. Exergy-a useful concept (3rd edition). Physical Resource Theory Group. Göteborg.

Wen, C., M. Xu, D. Yu, C. Sheng, H. Wu, P. Zhang, Y. Qiao and H. Yao, 2012. $\mathrm{PM}_{10}$ formation during the combustion of $\mathrm{N}_{2}$-char and $\mathrm{CO}_{2}$-char of Chinese coals. Proceedings of the Combustion Institute (in press). DOI: 10.1016/j.proci.2012.07.080

Yuan, S., Z. Dai, Z. Zhou, X. Chen, G. Yu and F. Wang, 2012. Rapid co-pyrolysis of rice straw and a bituminous coal in a high-frequency furnace and gasification of the residual char. Bioresource Technol., 109: 188-197. DOI: 10.1016/j.biortech.2012.01.019
Zain, M.F.M., M.N. Islam, F. Mahmud and M. Jamil, 2011. Production of rice husk ash for use in concrete as a supplementary cementitious material. Construction Building Materials, 25: 798-805. DOI: 10.1016/j.conbuildmat.2010.07.003

Zhang, Y., A.E. Ghaly and B. Li, 2012. Physical properties of rice residues as affected by variety and climatic and cultivation conditions in three continents. American Journal of Applied Sciences, 9: 1757-1768. DOI: 10.3844/ajassp.2012.1757.1768.

Zhang, Y., B. Li, H. Li and H. Liu, 2011. Thermodynamic evaluation of biomass gasification with air in autothermal gasifiers. Thermochimica Acta, 519: 65-71. DOI: 10.1016/j.tca.2011.03.005

Zhao, Y., S. Sun, H. Che, Y. Guo and C. Gao, 2012. Characteristics of cyclone gasification of rice husk. Int. J. Hydrogen Energy, 37: 16962-16966. DOI: 10.1016/j.ijhydene.2012.08.093 